\title{
Emotional Metaphors in the Glorious Quran with Reference to Their Realizations in English
}

\author{
Sufyan M. Hammood, Raneen W. Khalid \\ Department of English, College of Arts, Imam Ja'afar Al-Sadiq University, Baghdad, Iraq.
}

\begin{abstract}
Metaphors are an essential part of human experience. Each person depends on their everyday experience in relation to the linguistic system so that an image is created in their mind. The purpose of this study is to investigate metaphors of emotions in the Glorious Quran from a cognitive perspective. Throughout conceptual metaphors, readers structure and understand the abstract concepts in terms of more concrete ones. They perform more significant functions when they are used in the language of the Glorious Qur'an which has intellectual, psychological and aesthetical significances. Using a threedimensional model to analyze the data which consists of the following; First, Lakoff and Johnson's Metaphors We Live By in its two editions (1980) and (2003). Second, Arabic data depends on Al-Hayani (Metaphor in The Glorious Qur'an: Its Patterns and Rhetorical Meanings) (2016) who classifies meanings into three types; intellectual, psychological and aesthetic. Third, Newmarks' (1988) model of translation is also adopted. In this study, six Ayahs contain different types of emotions from the Glorious Quran are analyzed. The miraculous nature of the Glorious Qur'an is represented by its language which, unlike ordinary language, underlies variety of meanings. As a result, three translations are chosen; Pickhtall (1930), Ali (1987) and Hilali and Khan (1996). This study concludes that metaphors of emotions have a decisive role in our daily experience.
\end{abstract}

Index Terms - Conceptual Metaphor, Emotional Metaphors, Interpretation of the Glorious Quran, Metaphor, Semantic Significances.

\section{INTRODUCTION}

Lakoff and Johnson (1980, p. 85) maintain that emotions are particularly a good area to begin with in studying conceptual metaphor because they are not clearly delineated in our experience in any direct fashion. Along the same line, Gibbs (1994, pp. 125-126) argues that before the Cognitive Metaphor Theory (CMT), many researchers already noticed the high incidence of figurative language when speakers talked about their emotions (e.g. Davietez,1969; Davietez and Mattis, 1964; Fainsibler and Ortony, 1987). What the CMT provides is a theoretical framework that explains these phenomena in a detailed and integrated way. Conceptual metaphors depend on our conceptual (everyday experience) in relation to the linguistic system in order to have the full image in the mind of any person. Meaning in cognitive semantics (henceforth, CS) is based on conventionalized conceptual structure, thus mental categories which people have shaped from their experience of the external world are reflected in a cognitive domain which contain the semantic structure (Saeed, 2003, p. 342). The miraculous nature of the Glorious Qur'an is represented by its language which, unlike ordinary language, underlies variety of meanings. Rhetoricians and linguists have shown an increasing interest in it. To the best of the researchers' knowledge, no previous study had tackled structural metaphors in The Glorious Qur'an. Consequently, the present study is an attempt to fill this gap.

The current study investigates the emotional metaphors in the Glorious Qur'an from a cognitive perspective. For conducting the present study, three translations of The Glorious Qur'an are selected which are Pickhtall (1930) Ali (1987) and Hilali and Khan (1996).

\section{A. Metaphor Between Objectivism And Experimentist Views}

Within this framework, metaphor is regarded as an optional, rhetorical and stylistic device, and it is thus relegated to the status of a secondary problem in aesthetics. This view dominates the Western tradition which is both objectivist and literalist in character. It is made up of related views about the nature of the world, how the mind works and how language expresses the world (Johnson, 1987, 1998; Lakoff 1987; Lakoff and Johnson, 1980; Lakoff and Johnson, 1999).

However, the banishment of metaphor from the realm of truth explains why metaphor is traditionally left to rhetoric and literary analysis, rather than being taken seriously by science, mathematics, and philosophy, which are truth - seeking enterprises (Lakoff and Johnson, 1999, p. 120). The traditional theory of metaphor is persisted for twenty - five hundred years in the philosophical and literary traditions. It fosters a number of empirically false beliefs about metaphor that becomes so deeply entrenches and they are taken as necessary truths, just as the traditional theory is taken as definitional (ibid.).

Lakoff and Johnson (1999, p. 119) state the following central tenets of the traditional theory of metaphor:

Journal of University of Human Development

Volume 5 No. 3(2019); DOI: 10.21928/juhd.v5n3y2019.pp182-189

Regular research paper: Published 19 August 2019

Corresponding author's e-mail: sufyanmahdi92@gmail.com,ranwkh92@gmail.com

Copyright (C) 2019 Sufyan M. Hammood, Raneen W. Khalid. This is an open access article distributed under the Creative Commons Attribution

License (CC BY-NC-ND 4.0) 
1. Metaphor is a matter of words not thought. Metaphor occurs when a word is applied not to what it normally designates, but to something else.

2. Metaphorical language is not part of the ordinary conventional language. Instead, it is novel and typically arises in poetry, rhetorical attempts at persuasion, and scientific discovery.

3. Metaphorical language is deviant. In metaphor, words are not used in their proper senses.

4. Conventional metaphorical expressions in ordinary everyday language are "dead metaphors", that is , expressions that once were metaphorical have become frozen into literal expressions.

5. Metaphors express similarities. That is, there are preexisting similarities between what words normally designate and what they designate when they are used metaphorically.

Yu (1995, p. 10) summarizes the features of the traditional or classical theory of metaphor by saying that substitution theory of metaphor traces back to Aristotle who regards metaphor as 'implicit' analogy and similarity between two things. All these theories have the same feature in considering metaphor as a linguistic phenomenon rather than conceptual process. CMT, against the traditional theory of metaphor and cognitive metaphor theory, proves an empirical evidence that metaphor is something related to cognitive psychology, linguistics and anthropology. It is a process of thinking rather than a linguistic phenomenon. Metaphor becomes widely known since the publication of Metaphors We Live By, by Lakoff and Johnson (1980). Lakoff and Johnson (1980, p. 3) prove the wrong assumptions of traditional theory because it regards metaphor as a literary device used by poets and writers rather than being used in our thought and action in everyday experiences. They (ibid) also, show that our "conceptual system and ordinary language are metaphorical in nature."

Gibbs (1999, p. 202) views metaphor as mental mapping in which we build our understanding into two domains of experience by structuring our knowledge from one domain of experience 'target' in terms of more concrete one 'source' usually from a different kind. Langacker (1987, p. 488) illustrates domains by saying that "it is a coherent area of conceptualization relative to which semantic units may be characterized". Yu (1995, p. 14) mentions that the conceptual theory of metaphor is a conceptual phenomenon rather than a linguistic one. Metaphor according to this theory, is a systematic process between two domains both of them are found in our daily experience.

Against the objectivist (disembodied mind) theories of metaphor, stands a major orientation that marshal empirical evidence from linguistics, psychology, and anthropology to show that metaphoric concepts are grounded in our bodily experience and thereby constrain our understanding and reasoning.

Lakoff and Johnson (1980) start the race by arguing that our basic abstract concepts are defined by clusters of inconsistent metaphors, most of which operate unconsciously and automatically to determine our understanding. What we think of as "literal" language underlies conceptual metaphors that define its conceptual structure and the inferences we draw from that structure.

The main concern of the experientialist view is the rejection of the objectivist view that there is an absolute and unconditional truth. Because metaphor unites reason and imagination, focus is laid on it. Moreover, reason, at the very least, involves categorization, entailment, and inference. Imagination, in one of its many aspects, involves seeing one kind of a thing in terms of another kind of that thing- what is called metaphorical thought. Metaphor is thus an imaginative rationality. The categories of our everyday reasoning involves metaphorical entailments and inferences, thus ordinary rationality is imaginative by its very nature (Lakoff and Johnson, 1980, pp. 192-193).

All in all, within the CMT, metaphor is one of the basic cognitive mechanisms, it determines a large part of lexical and grammatical meanings and forms (Lakoff, 1987, pp. 462-585, 1993; Goldberg 1995; Sweetser, 1990, pp. 49-149 - cited in Barcelona, 1997, pp. 11-12). Moreover, it plays a role in thought and reasoning. Thus, this new perspective looks at metaphor as:

1. Metaphor is not simply a matter of language, but also (and fundamentally) a matter of thought, metaphors play their role in our thinking.

2. Metaphors are one of the building blocks of our conceptual system and they are embodied (since thought in general is embodied). In other words, the first original source of any metaphorical mapping is our physical and cultural experience.

3. Metaphors are not only rhetorical and literary devices. They are ubiquitous in all linguistic manifestations, and even in non- linguistic ones, like gestures (McNeill, 2000, p. 50). This happens because metaphor is a way of thinking and therefore underlies every type of expression of our thoughts.

4. Many cognitive linguists reject the classical distinction between literal and metaphorical language because it is superficial, confusing and in many cases unnecessary.

5. Linguistic meaning is gestalt -like. This implies that metaphorical expressions cannot be paraphrased and still communicate the same meaning. Any formal transformation in language implies a change in meaning.

6. Metaphor is not necessarily based on similarity.

Lakoff and Johnson (2003, p. 8) give an example about how metaphor is found in our daily experiences. One can start with the concept of TIME and conceptual metaphor (1) TIME IS MONEY
A. Time is money.
B. You're wasting my time.

These examples show that the concept of 'TIME' used not with the word 'MONEY', but has many linguistic expressions, because time is always associated with work so it is compared 
to money.

Traditional theories of metaphor receive criticisms by many linguists and writers. One of them is that of Lakoff (cited in $\mathrm{Yu}, 1995$, p. 10) who points out that traditional theories are built on literary-figurative distinction because they define the word literal as "an idealized and oversimplified model of language and thought" including the terms conventional, ordinary, nonmetaphorical and what is called truth conditional.

\section{B. Metaphor and Emotions}

Emotions are an effective element of human experience, human beings differ from animals not only in emotions, but also in the ways of expressing emotions. Emotions are expressed by both the physical and psychological sphere (Athanasiadou and Tabakowska ,1998, p. i). Emotions are central aspect of human life since cognitive influences and is influenced by emotions (Ortony et al, 1988, p. 3). Emotions are not understood without conceptualization of language because language is a tool for translating human's emotions (Kovecses ,2003, p. 3).

Gibbs (1997, pp. 146-147) argues that metaphor has a strong relationship with emotions because many concepts especially abstract ones are partially structured by metaphorical mapping of information from a familiar source domain to less familiar target domain. For example, people structure one type of emotions in different physical domain, they conceptualize the term love by mapping their pieces of information of the physical journey into their knowledge of love, LOVE IS JOURNEY. For cognitive semanticist, metaphorical and metonymic expressions reflect all aspects of emotions like anger, fear, sadness, disgust, shame and happiness. Example from (Kovecses, 2000, p. 24) are:

\section{HAPPY IS LIGHT}

She brightened up at the news.

\section{SAD IS DARK}

$\mathrm{He}$ is in direct a direct.

\section{LOVE IS A PHYSICAL FORCE}

I was magnetically down to here.

\section{PRIDE IS AN ECONOMIC VALUE}

Do not underestimate yourself.

Recently, the study of human emotions from a linguistic perspective achieve noticeable results. Two approaches study the emotional concepts linguistically which are:

1. Natural semantic metalanguage

2. Lakoff and Johnson Cognitive Theory of Metaphor.

Natural semantic metalanguage is an approach emerges by Anna Wierzbicka. The main concern of this approach is "there is language especially of linguistic meanings" since an expression really has an equivalent translation in another language. Wierzbicka pays an attention to lexical items which name emotions. For her, emotions are semantic components and to be studied in semantic metalanguage in terms of semantic universals that are shared by all languages (Wierzbicka, 1995, p. 235). Harkins and Wierzbicka (2001, p. 9) show that all efforts to study "human emotions in term of ordinary English or any other language lead to deformity, because every language naturally has its own native perspective to picture the world. Similarly, colour terms have effective role in emotional conceptualization across different languages and cultures. Different languages use different colour terms to describe the intensity of different emotions. For example, English use RED to describe the highest degree of anger whereas Arabic use BLACK.

\section{I was beginning to see red}

$$
\text { اسودت الدنيا في عيني }
$$

Yu (2002, p. 346) explains that Chinese uses red-eyes to describe jealous people whereas English uses green-eyes to describe people with the same emotion above.

\section{Metaphor In Arabic Culture}

Arabs before Islam knew the term البلاغة 'Al-Balagha' and its measures. This term helps in understanding and criticizing any speech depending on their experiences. According to many Arab rhetoricians على البيان, Ilmu-Bayan (the science of tropes) is the science that deals with the art of expressing oneself eloquently and explicitly without ambiguity (Al-Hashimi, 2008, p. 55).

Metaphor is one of the rhetorical devices of Ilmu- Bayan, which is related to the cognitive transference. Throughout this concept, one expresses any speech by using the minimum number of words to reflect deeper meanings.

Al-Jurjani (1954, p. 29) defines الاستعارة (metaphor) as a word in which its basic meaning is known to language users and is temporarily lent as it was, to something other than the original object.

Abdul-Raouf (2006, p. 218) mentions the term (metaphor) is derived from the verb أعار (to borrow), i.e., borrowing a feature from someone or something and applying it to someone or something else. Arab rhetoricians divide metaphor into three types: explicit, implicit, and proverbial metaphor. Explicit metaphor is firstly recognized by AlJurjani(1969, p. 106) who explains the process of exchanging which is made between two things in order to make something like something else, without any reference to the thing that we borrow its features. Matlub (1964, p. 268) defines explicit metaphor as a transference of meaning from its original use in language for a different purpose. This purpose is either to describe meaning or to exaggerate by referring to their realization through using minimum number of words. He (ibid) also comments that this type of metaphor gives speech aesthetic and artistic values, especially in expressing the meanings of The Glorious Qur'an.

As-Sakaki (1937, p. 176) divides explicit metaphor into two types; investigative and imaginative. Investigative means that the process of likening involves something tangible. It is either sensory or mental. Imaginative means likening comprises something abstract, which is not realized. In this type, the source domain exists in the sentence, but target domain is elliptic which depends on our everyday experience. Another type of Arabic metaphor is implicit metaphor. Al-Jurjani is the first one who recognizes this type, but As- Sakaki is the one who names it as Al- IstiaraAlmakania. Al-Jurjani (1969, p. 106) 
considers this type as a likening process that does not exceed out of one's imagination, by adding something that does not exist in the feature of likening. This type exists in The Glorious Qur'an in many Ayas. It reflects sensory experience in our life to depict reasonable and moral images by changing our sensory and visual image. The context in the Glorious Qur'an, in addition to its linguistic and aesthetic values, has a strong overtone that affects the hearer/reader understanding and the processes of imagination as in the example below in this Aya:

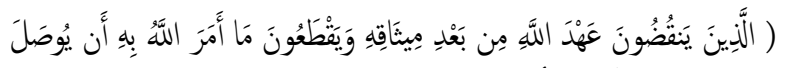

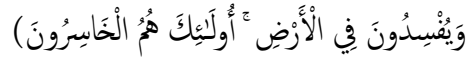

$$
\begin{aligned}
& \text { البقرة: YV }
\end{aligned}
$$

"Those who break Allah's Covenant after ratifying it, and sever what Allah has ordered to be joined (as regards Allah's Religion of Islamic Monotheism and to practice its legal laws on the earth and also as regards keeping good relations with kith and kin), and do mischief on earth, it is they who are the losers." (Hilali and Khan, 1996, p. 7).

The phrase 'break Allah's Covenant' expresses meaning, and introduces it in a sensory visual image by the transference of the sensory domain (rope) for another domain in order to express Allah's pact as faith.

Abu Musa (1980, p. 230) describes another type of metaphor known as proverbial metaphor. He says that this type is concerned with analyzing sensory image with all its causes, effects, actions, and all its aspects by making a comparison between two images. This type is not about replacing one word with another, but it is about the processes that are more comprehensive by mixing two or more states with each other in order to have the exact image..

\section{DATA ANALYSIS, DISCUSSIONS AND FINDINGS}

In this section, the data are analyzed by referring to their interpretations and discussions. To facilitate cross-reference in the analysis, these data are represented in tables.

\section{A. The Model Adopted}

The model adopted in the current study is a threedimensional one. The first dimension is Lakoff and Johnson's Metaphors We Live By in its two editions (1980) and (2003) which is adopted to study conceptual metaphors in The Glorious Qur'an. The second dimension of the model is related

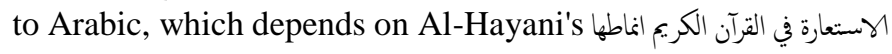
ودلالاتها البلاغية Rhetorical Meanings) (2016) who classifies meanings into three types; intellectual, psychological and aesthetic. For the sake of this study, the term 'semantic significance' is used instead of 'rhetorical meaning' to achieve congruity of terms in that the study adopts a cognitive rather than a traditional approach of metaphor. The third dimension is the type of translation in which Newmarks' (1988) model of translation is adopted. The Quranic translations are Pickthall (1930), Ali (1987) and Hilali and Khan (1996) are referred to 1,2, and 3 respectively in the tables of data analysis.

\section{B. Data Analysis}

\section{SL Text (1)}

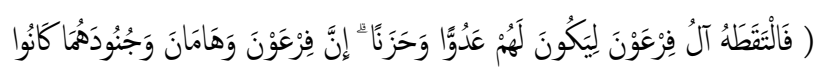

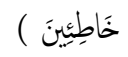

القصص: 1

TL Texts

1. And the family of Pharaoh took him up, that he might become for them an enemy and a sorrow. Lo! Pharaoh and Haman and their hosts were ever sinning (Pickthall, 1930, p. 122).

2. Then the people of Pharaoh picked Him up (from the river): (it was intended) that (Moses) should be to them an adversary and a cause of sorrow: for Pharaoh and Haman and (all) their hosts were men of sin (Ali, 1987, p. 261).

3. Then the household of Fir'aun (Pharaoh) pick him up, that he might become for them an enemy and a (cause of) grief. Verily! Fir'aun (Pharaoh), Haman and their hosts were sinner (Hilali and Khan,1996, p. 516).

\section{Interpretation}

In this Aya the metaphorical expression (ليكون لم عدوا و حزنا) expresses the emotion of sadness which is a punishment because of their disobedience of Allah's rules. Instead of being happy by having a new baby, they have the opposite 'sadness' (Ibn-Ashur, 1984, pp. 61-62).

\section{Discussion}

In this Aya the emotional metaphor is a structural one, because it shows the prophet Musa as an emotion of sadness for Pharaoh. Translation (1) is semantic as it conveys this metaphorical expression semantically. It conveys the content of the message faithfully. Whereas translations (2) and (3) are communicative by conveying the force of the message freely. The semantic significance is psychological because it describes the perfect use of metaphorical emotions in giving emotions a feature of human beings.

The processes of conceptual mapping, in this Aya, are used for understanding the target domain 'SADNESS' in terms of the source domain as ' PERSON' (birth of Musa), here, sadness is a person.

\begin{tabular}{|c|c|c|c|c|}
\hline & \multicolumn{2}{|c|}{$\begin{array}{c}\text { Translation } \\
\text { (1) }\end{array}$} & $\begin{array}{l}\text { Translation } \\
\text { (2) }\end{array}$ & $\begin{array}{c}\text { Translation } \\
\text { (3) }\end{array}$ \\
\hline \multirow[b]{2}{*}{$\begin{array}{c}\text { Types of } \\
\text { Translation }\end{array}$} & Semantic & + & 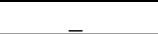 & \\
\hline & Communicative & - & - & + \\
\hline \multirow{3}{*}{$\begin{array}{l}\text { Types of } \\
\text { metaphor }\end{array}$} & Orientational & _ & _ & _ \\
\hline & Ontological & & & \\
\hline & Structural & + & + & + \\
\hline \multirow{3}{*}{$\begin{array}{l}\text { Semantic } \\
\text { Significance }\end{array}$} & Intellectual & & 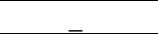 & 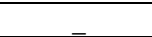 \\
\hline & Psychological & + & + & + \\
\hline & Aesthetic & & & \\
\hline \multirow{2}{*}{$\begin{array}{c}\text { Conceptual } \\
\text { Mapping }\end{array}$} & $\begin{array}{c}\text { Source } \\
\text { Domain }\end{array}$ & Person & Person & Person \\
\hline & $\begin{array}{c}\text { Target } \\
\text { Domain }\end{array}$ & Sadness & Sadness & Sadness \\
\hline
\end{tabular}

Table (1) Analysis of the Domain of SADNESS 
SL Text (2)

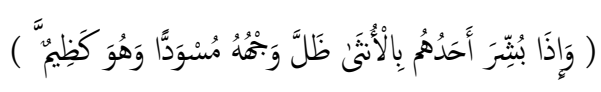

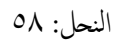

TL Texts

1. When if one of them receiveth tidings of the birth of a female, his face remaineth darkened, and he is wroth inwardly (Pickthall,1930, p. 83).

2. "When the news is brought to one of them, of (the birth of) a female (child), his face darkens, and he is filled with inward grief!" (Ali, 1987, p. 670).

3. "And when the news of ( the birth of ) a female (child) is brought to any of them, his face becomes dark, and he is filled with inward grief!" (Hilali and Khan, 1996, p. 354).

\section{Interpretation}

The above verse describes the manner of the disbeliever whenever he is announced that a baby girl is born. The word shows the degree of sadness and anger instead of happiness (Ibn-Ashur,1984, p. 184).

\section{Discussion}

Black colour in this Aya is described differently from the previous Aya to emphasize how Islam equalize all members of the society. Translation (1) is a semantic one, while translations (2) and (3) are communicative because the colour term is omitted. The semantic significance is intellectual because it makes one think about the concept of shame in terms of black face of people and how the Quranic metaphors help construct the image in his mind. In this Aya conceptual metaphor is a structural one because through the source domain BLACK COLOUR, the target domain SHAME and the processes of conceptual mapping are completed.

Table (2) Analysis of the Domain of SHAME

\begin{tabular}{|c|c|c|c|c|}
\hline & \multicolumn{2}{|c|}{$\begin{array}{c}\text { Translation } \\
\text { (1) }\end{array}$} & $\begin{array}{c}\text { Translation } \\
\text { (2) }\end{array}$ & $\begin{array}{c}\text { Translation } \\
\text { (3) }\end{array}$ \\
\hline \multirow[b]{2}{*}{$\begin{array}{l}\text { Types of } \\
\text { Translation }\end{array}$} & Semantic & + & - & - \\
\hline & Communicative & - & + & + \\
\hline \multirow{3}{*}{$\begin{array}{l}\text { Types of } \\
\text { Metaphor }\end{array}$} & Orientational & - & - & - \\
\hline & Ontological & - & - & - \\
\hline & Structural & + & + & + \\
\hline \multirow{3}{*}{$\begin{array}{l}\text { Semantic } \\
\text { Significance }\end{array}$} & Intellectual & + & + & + \\
\hline & Psychological & - & - & - \\
\hline & Aesthetic & - & - & - \\
\hline \multirow{2}{*}{$\begin{array}{l}\text { Conceptual } \\
\text { Mapping }\end{array}$} & $\begin{array}{l}\text { Source } \\
\text { Domain }\end{array}$ & $\begin{array}{l}\text { Black } \\
\text { Colour }\end{array}$ & $\begin{array}{l}\text { Black } \\
\text { colour }\end{array}$ & $\begin{array}{l}\text { Black } \\
\text { colour }\end{array}$ \\
\hline & $\begin{array}{l}\text { Target } \\
\text { Domain }\end{array}$ & Shame & Shame & Shame \\
\hline
\end{tabular}

\section{SL Text (3)}

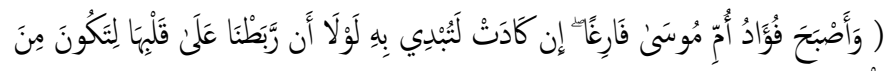

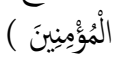

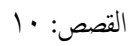

\section{TL Texts}

1. "And the heart of the mother of Moses became void, and she would have betrayed him if We had not fortified her heart, that she might be of the believers" (Pickthall,1930, p. 123).

2. "But there came to be a void In the heart of the mother of Moses: she was going almost to disclose His (case)", "had we not strengthened Her heart (with faith), so that she might remain a (firm) believer" (Ali,1987, p. 261).

3. "And the heart of the mother of Musa (Moses) became empty [from every thought, except the thought of Musa (Moses)]. She was very near to disclose his (case, i.e. the child is her son), had We not strengthened her heart (with Faith), so that she might remain as one of the believers." (Hilali and Khan,1996, p. 517).

\section{Interpretation}

In this Aya, the word فؤاد(means mind) is a metaphorical expression for the emptiness of Musa's mother mind . Her mind is without thoughts or ideas because of the degree of grief. Musa's mother thinks that when she puts him in the sea, he will die (Ibn-Ashur, 1984, pp. 80-82).

\section{Discussion}

The ontological metaphor, in this Aya, shows the mind of Musa's mother as a container for not only thoughts and ideas, but also for the emotions of sadness and patience. The mind can be filled with ideas and thoughts in a state of happiness. Thus, her mind is empty of nothing except Musa. Translations (1) and (2) are semantic because they translate the word فؤاد as heart not mind whereas, translation (3) is communicative. The semantic significance in this Aya is psychological because it shows how the mind is a container of emotions. It describes the emotions of Musa's mother even when she knows that Almighty Allah will return her son back.

Through conceptual mapping, the mind is considered as a container of emotions and they are as fluid in it. The MIND is a source domain whereas the emotion of SADNESS is a target domain.

Table (3) Analysis of the Domain of SADNESS

\begin{tabular}{|c|c|c|c|c|}
\hline & \multicolumn{2}{|c|}{$\begin{array}{c}\text { Translation } \\
(1)\end{array}$} & $\begin{array}{c}\text { Translation } \\
(2)\end{array}$ & $\begin{array}{c}\text { Translation } \\
(3)\end{array}$ \\
\hline \multirow{4}{*}{$\begin{array}{c}\text { Types of } \\
\text { Translation }\end{array}$} & Semantic & + & + & - \\
\cline { 2 - 5 } & Communicative & - & - & + \\
\hline \multirow{4}{*}{$\begin{array}{c}\text { Types of } \\
\text { Metaphor }\end{array}$} & Orientational & - & - & - \\
\cline { 2 - 5 } & Ontological & + & + & + \\
\cline { 2 - 5 } Semantic & Structural & - & - & - \\
\cline { 2 - 5 } Significance & Intellectual & - & - & - \\
\cline { 2 - 5 } & Psychological & + & + & + \\
\cline { 2 - 5 } & Aesthetic & - & - & - \\
\hline Conceptual \\
Mapping & $\begin{array}{c}\text { Source } \\
\text { Domain }\end{array}$ & Mind & Mind & Mind \\
\cline { 2 - 5 } & $\begin{array}{c}\text { Target } \\
\text { Domain }\end{array}$ & Sadness & Sadness & Sadness \\
\hline
\end{tabular}




$$
\begin{aligned}
& \text { SL Text (4) }
\end{aligned}
$$

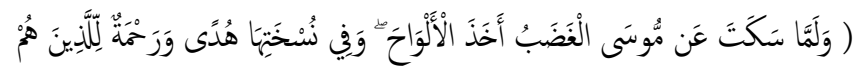

$$
\begin{aligned}
& \text { الأعراف: ع } 10
\end{aligned}
$$

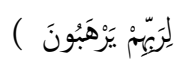

TL Texts

1. "Then, when the anger of Moses abated, he took up the tablets, and in their inscription there was guidance and mercy for all those who fear their Lord" (Pickthall,1930, p. 50).

2. "When the anger of Moses was appeased, he took up the tablets: in the writing thereon was guidance and Mercy for such as fear their Lord" (Ali,1987, p. 103).

3. "And when the anger of Moses was calmed down, he took the tables, and their inscription was guidance and mercy for those who fear their Lord" (Hilali and Khan. 1996, p. 222).

\section{Interpretation}

In this Aya, the concept of anger is used metaphorically to express how Moses' anger has gone away. This metaphorical expression illustrates how the outburst of anger changes the mood of any person and makes them behave aggressively. Yet, when anger goes away that person will be normal again (Ibn Ashur, 1894, pp. 121-122).

\section{Discussion}

This Aya includes the metaphorical expression of how the emotion of anger is considered as a person, 'physical object'. The concept of anger has some features of human beings that it can be 'appeased'. This feature is related to humans not to emotions. Anger does not calm itself down, but the person who gets angry goes back to his state of being normal. This type of metaphor is known as an ontological metaphor because it uses the process of personification. The three translators tackle this metaphorical expression differently. Translations (1), (2) are semantic because they translate this metaphorical expression semantically by conveying the content of the message faithfully, whereas translation (3) renders this metaphorical expression communicatively by conveying the force of the massage freely. The semantic significance of this Aya is a psychological one because it describes the perfect use of the metaphorical expression by giving the feature of something to something else. It also, describes how the emotion of anger, under certain circumstances, affects the mood of any person.

The processes of the conceptual mapping, in this Aya, are used for understanding the target domain 'ANGER' in terms of a source domain which is the behavior of Moses 'HUMAN BEING' (anger as a physical object). When he gets back to his state of being calm down, here 'anger' is considered as a person.
Table (4) Analysis of the Domain of ANGER

\begin{tabular}{|c|c|c|c|c|}
\hline & \multicolumn{2}{|c|}{$\begin{array}{c}\text { Translation } \\
\text { (1) }\end{array}$} & $\begin{array}{c}\text { Translation } \\
\text { (2) }\end{array}$ & $\begin{array}{c}\text { Translation } \\
\text { (3) }\end{array}$ \\
\hline \multirow[b]{2}{*}{$\begin{array}{c}\text { Types of } \\
\text { Translation }\end{array}$} & Semantic & + & + & - \\
\hline & Communicative & - & - & + \\
\hline \multirow{3}{*}{$\begin{array}{l}\text { Types of } \\
\text { metaphor }\end{array}$} & Orientational & _ & - & - \\
\hline & Ontological & + & + & + \\
\hline & Structural & - & - & - \\
\hline \multirow{3}{*}{$\begin{array}{l}\text { Semantic } \\
\text { Significance }\end{array}$} & Intellectual & _- & _ & _ \\
\hline & Psychological & + & + & + \\
\hline & Aesthetic & - & - & - \\
\hline \multirow{2}{*}{$\begin{array}{c}\text { Conceptual } \\
\text { Mapping }\end{array}$} & $\begin{array}{c}\text { Source } \\
\text { Domain }\end{array}$ & $\begin{array}{c}\text { Human } \\
\text { being }\end{array}$ & $\begin{array}{c}\text { Human } \\
\text { being }\end{array}$ & $\begin{array}{c}\text { Human } \\
\text { being }\end{array}$ \\
\hline & $\begin{array}{c}\text { Target } \\
\text { Domain }\end{array}$ & Anger & Anger & Anger \\
\hline
\end{tabular}

\section{SL Text (5)}

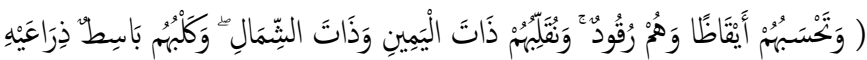

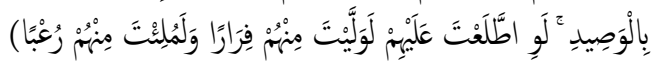

\section{TL Texts}

1. "And thou wouldst have deemed them waking thou they were asleep, and we caused them to turn over to the right and the left, and their dog stretching out his paws on the threshold". "If thou hadst observed them closely thou hadst assuredly turned away from them in flight, and hadst been filled with awe of them"(Pikthall,1930, p. 90).

2. "Thou wouldst have deemed them awake, whilst They asleep, and we turned them on their right and on their left sides: their stretching forth His two fore-legs on the threshold": "if Thou hadst come up to them, Thou wouldst have certainly turned back from them In flight, and certainly have been filled with terror of them"(Ali,1987, p. 191)

3. "And you would have thought them awake, while they were asleep. And We turned them on their right and on their left sides", "and their dog stretching forth his two forelegs at the entrance of the Cave or in the space near to the entrance of the Cave (as a guard at the gate)". "Had you looked at them, you would certainly have turned back from them in flight, and would certainly have been filled with awe of them" (Hilali and Khan,1996, p. 387 ).

\section{Interpretation}

This Aya is not for certain people, but for all hearers and readers in general. When the cave's owners are seen, anyone would surely have turned back in fear without thinking and awe will possess him. The phrase ولملئت منهم رعبا is meant 'you' the hearer/ reader will be filled with awe because the time of this story has passed. Also, the same phrase above comes to show exaggeration (Inb-Ashur,1984, pp. 281-283).

\section{Discussion}

In the Aya above, the metaphorical expression ولملئت منهم رعبا (and would certainly have been filled with awe of them) perfectly describes the degree of fear that people felt at that 
moment. The body of a human is considered as a container for an emotion 'fear'. Emotions are here as fluid in this container that when anyone sees the cave's owners, he is filled with fear. This type of metaphor is known as ontological. All translations are semantic because they translate the words faithfully. The semantic significance is psychological because this Aya describes fear as something strong that no one can face.

The conceptual mapping, in this Aya, depends on a source domain which is the body of human being in considering it as' HUMAN BODY ' to understand the target domain 'FEAR'.

Table (5) Analysis of the Domain of FEAR

\begin{tabular}{|c|c|c|c|c|}
\hline \multirow{3}{*}{$\begin{array}{c}\text { Types of } \\
\text { Translation }\end{array}$} & \multicolumn{2}{|c|}{$\begin{array}{c}\text { Translation } \\
(1)\end{array}$} & Cranslation & $\begin{array}{c}\text { Translation } \\
(2)\end{array}$ \\
\cline { 2 - 5 } & Communtic & + & + & + \\
\hline \multirow{3}{*}{$\begin{array}{c}\text { Types of } \\
\text { Metaphor }\end{array}$} & Orientational & - & - & - \\
\cline { 2 - 5 } & Ontological & + & + & + \\
\cline { 2 - 5 } & Structural & - & - & - \\
\hline \multirow{3}{*}{$\begin{array}{c}\text { Semantic } \\
\text { Significance }\end{array}$} & Intellectual & - & - & - \\
\cline { 2 - 5 } & Psychological & + & + & + \\
\cline { 2 - 5 } & Aesthetic & - & - & - \\
\hline \multirow{3}{*}{$\begin{array}{c}\text { Conceptual } \\
\text { Mapping }\end{array}$} & $\begin{array}{c}\text { Source } \\
\text { Domain }\end{array}$ & $\begin{array}{c}\text { Human } \\
\text { body }\end{array}$ & $\begin{array}{c}\text { Human } \\
\text { body }\end{array}$ & Human body \\
\cline { 2 - 5 } & $\begin{array}{c}\text { Target } \\
\text { Domain }\end{array}$ & Fear & Fear & Fear \\
\hline
\end{tabular}

SL Text (6)

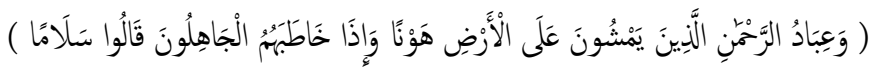

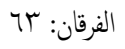

\section{TL Texts}

1. "The (faithful) slaves of the Beneficent are they who walk upon the earth modestly, and when the foolish ones address them answer: Peace" (Pickthall,1930, p. 114).

2. "And the servants of (Allah) Most gracious are those who walk on the earth in humility, and when the ignorant address them, They say, "Peace!" (Ali,1987, p. 244).

3. "And the slaves of the Most Beneficent (Allah) are those who walk on the earth in humility and sedateness, and when the foolish address them (with bad words) they reply back with mild words of gentleness." (Hilali and Khan,1996, p. 485).

\section{Interpretation}

Another sign is the way Muslims must behave even in walking. This Aya describes the features of the believers as they work without showing off their works. The Almighty Allah orders believers to leave the foolish when they address them with bad words (Inb-Ashur, 1984, pp. 66-68).

\section{Discussion}

The structural metaphor in this Aya is understood by referring to the humility of the believers in terms of walking 'motion'. All translations are semantic reflecting the faithful way of translating the way the believers walk. The semantic significance is aesthetic because it describes the beauty and the mortality of Islam in which silence sometimes is more effective than speech.

The source domain 'MOTION' helps to understand the target domain emotion of 'HUMILITY' thus, the processes of conceptual mapping are completed.

Table (6) Analysis of the Domain of HUMILITY

\begin{tabular}{|c|c|c|c|c|}
\hline & \multicolumn{2}{|c|}{$\begin{array}{c}\text { Translation } \\
\text { (1) }\end{array}$} & $\begin{array}{c}\text { Translation } \\
\text { (2) }\end{array}$ & $\begin{array}{c}\text { Translation } \\
\text { (3) }\end{array}$ \\
\hline \multirow{2}{*}{$\begin{array}{l}\text { Types of } \\
\text { Translation }\end{array}$} & Semantic & + & + & + \\
\hline & Communicative & - & - & - \\
\hline \multirow{3}{*}{$\begin{array}{l}\text { Types of } \\
\text { Metaphor }\end{array}$} & Orientational & - & - & - \\
\hline & Ontological & - & - & - \\
\hline & Structural & + & + & + \\
\hline \multirow{3}{*}{$\begin{array}{c}\text { Semantic } \\
\text { Significance }\end{array}$} & Intellectual & - & - & - \\
\hline & Psychological & - & - & - \\
\hline & Aesthetic & + & + & + \\
\hline \multirow{2}{*}{$\begin{array}{l}\text { Conceptual } \\
\text { Mapping }\end{array}$} & $\begin{array}{c}\text { Source } \\
\text { Domain }\end{array}$ & Motion & Motion & Motion \\
\hline & $\begin{array}{c}\text { Target } \\
\text { Domain }\end{array}$ & Humility & Humility & Humility \\
\hline
\end{tabular}

\section{CONCLUSIONS}

Based on the analysis made in the previous section, the study has come up with certain conclusions which are in translating structural metaphors in the Glorious Qur'an, Pickthall (1930), on one hand, makes use of semantic translation only. No use is found for communicative translation. Hilali and Khan, on the other hand, show the least employment of semantic translation in translating structural metaphors in The Glorious Qura'n. In this regard, they exploit communicative translation more than the other two translators. Thus, it seems that semantic translation is more effective than communicative one in translating emotional metaphors.

Also, it is demonstrated that among semantic significances employed by means of structural metaphors in The Glorious Qur'an, psychological significance show the most abundant use. Finally, results of the study show that emotional metaphors facilitate understanding The Qur'anic Ayas. As they have a decisive role in determining the precise meaning of the Qur'anic texts. Their employment in The Glorious Qur'an represents one of the aspects of its uniqueness and inimitability.

\section{REFERENCES}

Abdul-Raof, H. (2006). Arabic Rhetoric: A Pragmatic Analysis. Routledge, New York.

Aristotle. (1950) Rhetoric and Poetics. Translated by M.C. Butcher, in Nahm Ed.

(1962). The Poetics. Oxford: The Clarendon Press. Translated by: Ingram By water.

As-Saboni, M. (1976). Safwat Al-tafaseer. Cairo: Dar Al-Hikma

Athanasiadou, A., \& Tabakowska, E. (1988) Speaking of Emotions: Conceptualisation and Expression. Berlin: Walter De Gruyter.

Barcelona, A.(1997). Cognitive Linguistics: A Usable Approach. In: Barcelona, A. (ed.), Cuaderons de Filologia Inglesa,6-2, (Special issue) Cognitive Linguistics In The Study of The English Language and Literature In English. Murica : Univesidad de Mucia, pp.7-32. 
Gibbs, R.W.Jr. (1994).The Poetics of Mind: Figurative Thought, Language, and Understanding. New York: Cambridge University Press.

Gibbs, R.W.Jr. (1997). Taking metaphor out of our heads and putting it into the cultural world. In: Gibbs,R.W.Jr and G. Steen (eds.). Metaphor In Cognitive Linguistics. Amsterdam: John Benjamins Publishing Company, pp.145-166.

Gibbs, R.W.Jr. (1999). Metaphor. Encylopedia of Creativity, vol.2, pp.209219.

Harkins, J. \& A. Wierzbicka (eds.) (2001). Emotions in Crosslinguistic Perspective. Berlin and New York : Mouton de Gruyter.

Kovecses,Z. (2002). Metaphor: A Practical Introduction. Oxford: Oxford University Press.

Kovecses,Z. (2003). Metaphor and Emotion: Language, Culture, and Body in Human Feeling. Cambridge, England: Cambridge University Press.

Lakoff, G \& M. Johnson. (1980). Metaphors We Live By. Chicago: Chicago University press.

Lakoff, G \& M. Johnson. (1999). Philosophy In Flesh The Embodied Mind and Its Challenge to Western Thought. New York: Basic Books.

Lakoff, G \& M. Johnson. (2003) Metaphors We Live By with A New Afterward. Chicago: The University of Chicago Press.

Langacker, R. (1987). Foundations of Cognitive Grammar. Vol.1: Theoretical Prerequisites. Stanford, California: Stanford University Press.

McNeill, D.(ed) (2000) Language and Gesture. Cambridge: Cambridge University Press.

Newmark, P. (1988a). Approaches to Translation. London: Prentice-Hall International Ltd.

Newmark, P. (1988b). A Textbook of Translation. London: Prentice-Hall International Ltd.

Ortony, A. (ed.). (1993). Metaphor and Thought. (2nd edition). Cambridge: Cambridge University Press.

Ortony, A., Clore, G. L., \& Collins, A. (1988). The Cognitive Structure of Emotions. New York: Cambridge University Press. http://dx.doi.org/10.1017/CBO9780511571299

Saeed, J. (2003). Semantics. (3rd Edition). Oxford: Willy-Blackwell.

Wierzbicka, A. (1995b). Emotion And Facial Expression : A Semantic Perspective. In : Culture and Psychology,1, pp.227-258.

Yu, N. (1995). Metaphorical expressions of anger and happiness in English and Chinese. Metaphor and Symbolic Activity, 10, pp. 59-92.

Yu, N. (2002). Body and Emotion: Body Parts in Chinese Expression of Emotion. In: Enfield, N. and A. Wierzbicka (eds.), The Body in Description of Emotion: Cross-Linguistic Studies. Pragmatics and Cognition, 10, (special issue), pp. 333-385.

\section{Qur'anic Translations}

Ali, A. Y. (trans.) (1987). The Qur'an : Text, Translation and Commentary. New York: Tahrike Quran. Inc.

Hilâli,T. \& Khân, M.(trans.)(1996) The Noble Qur'ân: English Translation of the Meaning and Commentary. King Fahad Complex for Printing The Holy Quran.

Pickthall, M. (trans.) (1930). The Meanings of the Glorious Qurān. Karachi: Jaj Art Press.

\section{Arabic References}

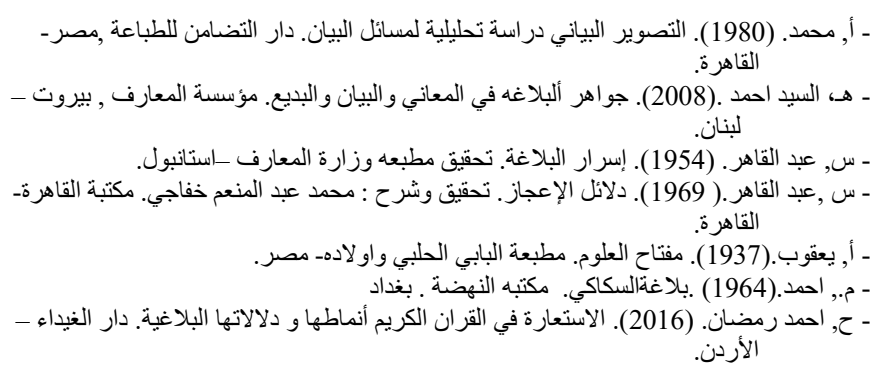

